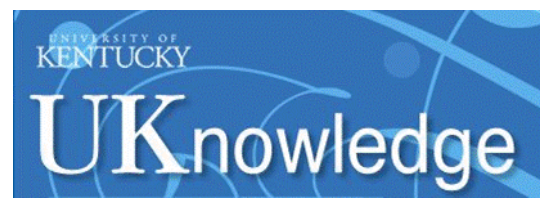

University of Kentucky

UKnowledge

\title{
Important Factors in Midwestern Public Librarians' Views on Intellectual Freedom and Collection Development: Part 1
}

Shannon M. Oltmann

University of Kentucky, shannon.oltmann@uky.edu

Follow this and additional works at: https://uknowledge.uky.edu/slis_facpub

Part of the Collection Development and Management Commons

Right click to open a feedback form in a new tab to let us know how this document benefits you.

\section{Repository Citation}

Oltmann, Shannon M., "Important Factors in Midwestern Public Librarians' Views on Intellectual Freedom and Collection Development: Part 1" (2019). Information Science Faculty Publications. 66.

https://uknowledge.uky.edu/slis_facpub/66

This Article is brought to you for free and open access by the Information Science at UKnowledge. It has been accepted for inclusion in Information Science Faculty Publications by an authorized administrator of UKnowledge. For more information, please contact UKnowledge@lsv.uky.edu. 


\section{Important Factors in Midwestern Public Librarians' Views on Intellectual Freedom}

and Collection Development: Part 1

\section{Digital Object Identifier (DOI)}

https://doi.org/10.1086/700659

\section{Notes/Citation Information}

Published in The Library Quarterly, v. 89, no. 1, p. 2-15.

(C) 2019 by The University of Chicago. All rights reserved.

The copyright holder has granted the permission for posting the article here. 


\title{
Important Factors in Midwestern Public Librarians' Views on Intellectual Freedom and Collection Development: Part 1
}

\author{
Shannon M. Oltmann
}

\begin{abstract}
This research project examined the beliefs and actions of US midwestern librarians concerning intellectual freedom and collection development. The results are presented in two complementary articles; this first article provides some background and the results pertaining to intellectual freedom, whereas the second article will focus on the results for collection development questions and conclude with a broader discussion. The data were obtained through an extensive survey with a $21.37 \%$ response rate. In general, high levels of support for intellectual freedom were found across most respondents and across multiple questions. Respondents with an MLS degree were more likely to be in alignment with ALA stances and to support intellectual freedom. Despite anecdotal suggestions that the political leaning of a community may influence support for intellectual freedom, that was not found in this survey. Finally, nearly $40 \%$ of respondents indicated tension between their personal beliefs and professional stances with regard to intellectual freedom.
\end{abstract}

n 1972, Charles Busha published his seminal work investigating intellectual freedom and censorship in midwestern public libraries. He focused on the Midwest because of time and financial restraints and because "the Midwest has frequently been referred to as the heartland of the North American continent, both geographically and functionally" (Busha 1972, 287). He sampled 900 librarians in a variety of positions across five states (Illinois, Indiana, Michigan, Ohio, and Wisconsin), examining attitudes toward intellectual freedom, censorship, and authoritarianism. Busha's demographic variables included age, sex, size of community, position of the librarian, state, and educational attainment level.

He reported that only $9 \%$ of librarians were "very definitely prointellectual [sic] freedom and anticensorship" (Busha 1972, 293). The mean intellectual freedom scores showed that most respondents were in agreement with the principles of the Library Bill of Rights (ALA 2018f). He found significant variation for the variables of educational attainment, size of community, sex, state, and librarian position. Finally, Busha found a relationship between librarians' attitudes

Library Quarterly: Information, Community, Policy, vol. 89, no. 1, pp. 2-15. (C) 2019 by The University of Chicago. All rights reserved. $0024-2519 / 2019 / 8901-0002 \$ 10.00$

2 
toward intellectual freedom and censorship and between censorship and authoritarian values (295). He concluded his study by stating "the data show a marked disparity between the attitudes of some librarians toward intellectual freedom as a concept and their attitude toward censorship as an activity" (300).

The research reported here is not a replication of Busha (1972) but was conducted in the same spirit. What are the attitudes and perspectives of midwestern librarians toward intellectual freedom and censorship?

\section{Literature Review}

Intellectual freedom is defined by the American Library Association (ALA) as "the right of every individual to both seek and receive information from all points of view without restriction. It provides for free access to all expressions of ideas through which any and all sides of a question, cause or movement may be explored" (ALA 2018d, par. 1). Intellectual freedom is focused on providing and enabling access to a broad array of ideas and perspectives, through diverse media, with as few restrictions as possible.

As Busha (1972) indicated, intellectual freedom is often positioned as the opposite of censorship, which is "those actions which significantly restrict free access to information" (Moody 2005, 139) or "the suppression of ideas and information that certain persons-individuals, groups or government officials-find objectionable or dangerous" (ALA 2018d, par. 4). Censorship in libraries is often preceded by a challenge- $\mathrm{a}$ formal request to withdraw, relocate, or restrict access to library materials (ALA 2018c). Censorship and intellectual freedom have long been concerns of librarians and scholars in the discipline. In 1953, Lester Asheim noted, "The real question of censorship versus selection arises when the librarian, exercising his own judgment, decides against a book which has every legal right to representation on his shelves" (par. 4).

The ALA has worked vigorously to explain and defend intellectual freedom, naming it one of librarianship's 11 core values, along with access to information (ALA 2018b). In addition, many principles of the ALA (2018a) Code of Ethics are explicitly concerned with intellectual freedom. The most relevant are the first, second, and seventh principles:

- We provide the highest level of service to all library users through appropriate and usefully organized resources; equitable service policies; equitable access; and accurate, unbiased, and courteous responses to all requests.

- We uphold the principles of intellectual freedom and resist all efforts to censor library resources.

- We distinguish between our personal convictions and professional duties and do not allow our personal beliefs to interfere with fair representation of the aims of our institutions or the provision of access to their information resources. 
As these principles make clear, intellectual freedom is central to contemporary conceptions of librarianship in the United States. It is a foundational belief that influences librarian perspectives on many topics, such as privacy, copyright, and the digital divide.

Perhaps the pinnacle of intellectual freedom is the Library Bill of Rights (ALA 2018f), first adopted in 1939 by the ALA and subsequently reaffirmed many times. According to this essential document, "Books and other library resources should be provided for the interest, information, and enlightenment of all people of the community the library serves. Materials should not be excluded because of the origin, background, or views of those contributing to their creation" (ALA 2018f, principle 1), and "Libraries should provide materials and information presenting all points of view on current and historical issues. Materials should not be proscribed or removed because of partisan or doctrinal disapproval" (principle 2). These statements provide further evidence of the centrality and significance of intellectual freedom for US librarianship. The ALA has also formally adopted 28 interpretations of the Library Bill of Rights that explain how the document applies to specific intellectual freedom-related topics such as access for minors, labeling systems, or meeting rooms (ALA 2018e).

Despite this evidence that intellectual freedom is central to librarianship, relatively little research systematically and empirically examines librarians' attitudes about and actions on intellectual freedom. Kathleen Monks, Anne Gaines, and Caitlin Marineau (2014) analyzed censorship and intellectual freedom by surveying public and school librarians in Idaho. According to their research, most respondents reported receiving no challenges to library materials, but those who were challenged often relocated or removed the challenged items.

Kim Moody (2004) surveyed Queensland, Australia, librarians to study attitudes and actions toward intellectual freedom, with the suspicion that actions were not always correlated with attitudes. Her respondents indicated strong anticensorship beliefs, which Moody then tested through hypothetical scenarios of purchasing controversial items. For example, respondents were asked if they would purchase "a guide to gay parenting" or "a video on the history of the Ku Klux Klan, produced and sold by the Ku Klux Klan" (Moody 2004, 176). Respondents could choose to purchase the item, purchase and label it, purchase it and place it on restricted access, or not purchase it. Only two items were rejected by a majority of respondents, both of which contained instructions for illegal activities (drug and bomb making). A minority of respondents (under 20\% for each item) indicated they would purchase the item then label or restrict access. Moody's respondents emphasized the need for balanced collections in their libraries. More than half of the respondents indicated they had experienced pressure to remove or label items, and approximately a quarter said they had declined to purchase an item because they feared controversy from their communities. Finally, a quarter of the respondents said their personal beliefs had been in conflict with their professional role.

Similarly, Michael Harkovitch, Amanda Hirst, and Jenifer Loomis (2003) wanted to see if there was conflict between personal and professional stances among librarians within the Seattle Public 
Library system. Most respondents were in favor of unrestricted internet access and in agreement with the ALA Code of Ethics, though approximately 37\% reported conflict with their personal beliefs. The authors noted that the librarian's role is to champion intellectual freedom, but in actual practice this can be difficult. Others have likewise suggested that librarians may not always uphold the strong ideals of intellectual freedom (Moody 2005; Knox 2014; Oltmann 2016).

In Shannon M. Oltmann's (2016) survey of Ohioan public librarians, the majority of respondents supported intellectual freedom, though nearly 40\% reported some conflict between their personal and professional beliefs. These librarians reported that having a balanced collection was an essential component of serving their communities. Variables such as the size of a community, the type (rural or urban), and the political leaning of the community were rarely significant, suggesting that even in small towns, rural areas, and conservative regions, librarians emphasized balanced collections. Gender was a frequently significant variable, but it must be interpreted with caution given the small number of male respondents. Similar to Moody (2004), most respondents did not choose to restrict or label hypothetical controversial materials; the percentage of respondents wanting to limit access was lower in Oltmann's study than in Moody's research.

The current research expands work described in Oltmann (2016) by surveying collection development librarians across the midwestern United States to determine their views and actions pertaining to intellectual freedom.

\section{Method}

The survey used in this research project was developed with Qualtrics software and used by Oltmann (2016). By using the same survey, we can better compare the results. The survey was sent out via a recruitment email in fall 2016. This included a link to the online survey, which contained 32 questions, including several open-response questions, and took approximately 15-25 minutes to complete. To ensure confidentiality, it was designed to not collect IP addresses.

This survey was sent to public library directors in nine midwestern states: Illinois, Indiana, Iowa, Kansas, Michigan, Minnesota, Nebraska, North Dakota, and Wisconsin. The Midwest region was chosen for three reasons: (a) it harkens back to Busha's (1972) seminal study and extends research by Oltmann (2016); (b) this region is often overlooked in research; (c) the Midwest region contains variance in terms of community size, political leaning, and location of MLS-producing graduate schools. ${ }^{1}$

1. The US midwestern region contains many small towns and rural areas but also includes large cities such as Chicago, St. Louis, and Kansas City. These large towns tend to be very diverse socioeconomically and in terms of race/ethnicity. Although much of the region tends to be conservative politically, there are many pockets of liberalism as well. Five of the nine states surveyed have universities with library science graduate programs. 
To initiate contact, the state librarian of each state was contacted and asked for collaboration, because this librarian had access to an email list of all public library directors in his or her state. The state librarian then either shared the email list with the researcher or sent out a recruitment email on her behalf. ${ }^{2}$ In this manner, the recruitment email with a link to the survey was shared with 3,018 library systems across the Midwest (see table 1). In the email, the library director was asked to share the survey link with the person primarily responsible for collection development (and if that was the director, then the director was to complete the survey). This wording was used to reduce the possibility of multiple librarians from one library taking the survey; the intention was that only one librarian per library would complete the survey, but it is not possible to confirm this occurred.

Of the 3,018 possible respondents, 645 completed at least some portion of the survey, for a response rate of $21.37 \%$. The state with the highest response rate was Illinois (22.5\%), followed by Minnesota (20.0\%), Nebraska (19.9\%), and Michigan (19.4\%). The state with the lowest response rate was Kansas (5.2\%). It is not clear why the response rates varied so much across states. As several state librarians noted, the survey was sent during the fall, when many public libraries are compiling state-mandated reports and completing required surveys; thus, library staff may have had survey or form fatigue and decided against completing one more survey. To protect respondents' confidentiality, responses in the following section will not be separated by state. Instead, other key demographic information will be used (see next section).

Data were analyzed statistically to determine if the findings are the result of mere chance or actual correlations. When statistical significance is reported, this means that the relationship is unlikely to occur because of mere chance; in fact, for statistically significant findings reported in this research, there is $95 \%$ probability that the items are correlated systematically, as opposed to occurring by chance (because we use $p=.05$ as the level of significance). Statistics were computed using chi-square for nominal variables and $t$-tests for comparing the means of a normally distributed interval dependent variable for two independent groups (for more explanation, see an introductory methods textbook, e.g., Connaway and Radford 2017).

\section{Results}

\section{Basic Demographics}

Respondents were asked a number of demographic questions (see table 2). Most respondents were female $(87.9 \%)$ and had worked in libraries for more than 10 years $(57.6 \%)$. Age was closely divided between those 45 years old or younger (41.6\%) and those older than 45 years (58.4\%). In addition, the characteristic of holding an MLS degree was nearly evenly split, with $51.7 \%$ having the degree but $48.3 \%$ not having the degree (time since completion of degree was not collected).

2. The state librarians from South Dakota and Missouri were contacted but declined to participate. Thus, librarians from these two Midwestern states are excluded. Librarians from Ohio are also excluded as they were surveyed previously by Oltmann (2016). 
Table 1. Response Rates from Midwestern States

\begin{tabular}{lccc}
\hline & $n$ Libraries & $n$ Respondents* & Response Rate (\%) \\
\hline Illinois & 639 & 144 & 22.5 \\
Indiana & 237 & 32 & 13.5 \\
lowa & 544 & 73 & 13.4 \\
Kansas & 328 & 17 & 5.2 \\
Michigan & 396 & 77 & 19.4 \\
Minnesota & 135 & 27 & 20.0 \\
Nebraska & 267 & 53 & 19.9 \\
North Dakota & 89 & 12 & 13.5 \\
Wisconsin & 383 & 45 & 11.7 \\
& & & \\
\hline
\end{tabular}

* 165 respondents did not indicate their state.

Respondents were also asked about the communities their libraries served (see table 3). This included information about the size, type, and political leaning of the community. Nearly two-thirds of respondents (60.7\%) were in small communities, with a third in midsize communities $(34.2 \%)$ and only $5.1 \%$ of respondents in large communities $(<100,000)$. Similarly, about half of respondents $(53.6 \%)$ reported they were in rural areas. Approximately $21.1 \%$ of respondents were in towns, $17.9 \%$ in suburbs, and only $7.4 \%$ in cities. Finally, most service areas were reported as conservative (65.5\%), with only $13.0 \%$ liberal and 21.5\% neutral (or unknown).

\section{Statements about Intellectual Freedom}

Respondents were asked whether they agreed with several statements about intellectual freedom (see table 4). Overall, respondents showed remarkable consistency on these items, with a

Table 2. Demographic Characteristics of Respondents

\begin{tabular}{lrr}
\hline Characteristic & $n$ & $\%$ \\
\hline Gender: & & \\
$\quad$ Female & 429 & 87.9 \\
$\quad$ Male & 54 & 11.1 \\
$\quad$ Other/prefer not to answer & 5 & 1.0 \\
Age: & & \\
$\quad 45$ years or younger & 203 & 41.6 \\
$\quad$ Older than 45 years & 285 & 58.4 \\
MLS degree: & & \\
$\quad$ Yes & 253 & 51.7 \\
$\quad$ No & 236 & 48.3 \\
Work duration: & & \\
$\quad<10$ years & 207 & 42.4 \\
$>10$ years & 281 & 57.6 \\
& & \\
\hline
\end{tabular}


Table 3. Characteristics of Respondents' Communities

\begin{tabular}{lrr}
\hline & $n$ & $\%$ \\
\hline Size of community: & & \\
$\quad<10,000$ & 296 & 60.7 \\
10,000-100,000 & 167 & 34.2 \\
$>100,000$ & 25 & 5.1 \\
Type of community: & & \\
$\quad$ Rural & 261 & 53.6 \\
Town & 103 & 21.1 \\
Suburb & 87 & 17.9 \\
City & 36 & 7.4 \\
Political leaning: & & 13.0 \\
Liberal & 63 & 21.5 \\
Neutral/don't know & 104 & 65.5 \\
Conservative & 317 & \\
& & \\
\hline
\end{tabular}

large majority ( $88 \%$ or higher) agreeing on every statement. For example, $88.6 \%$ of respondents agreed that "Public libraries should cater to public interest in contemporary issues without promoting or suppressing particular beliefs or ideas."

The statements with the strongest agreement were "Public libraries should provide their clients with access to information from a variety of sources" (98.4\%) and "Public libraries should RESIST attempts by individuals or groups to restrict access to information and ideas" (92.5\%). These are simple statements that echo the core values of the ALA, so it is perhaps not surprising to see strong support for these statements.

Table 4. Agreement with Statements about Intellectual Freedom and Collection Development

\begin{tabular}{|c|c|c|c|c|c|c|}
\hline & \multicolumn{2}{|c|}{ Agree } & \multicolumn{2}{|c|}{$\begin{array}{c}\text { Neither Agree } \\
\text { nor Disagree }\end{array}$} & \multicolumn{2}{|c|}{ Disagree } \\
\hline & $n$ & $\%$ & $n$ & $\%$ & $n$ & $\%$ \\
\hline $\begin{array}{l}\text { Public libraries should provide their clients with } \\
\text { access to information from a variety of sources. } \\
\text { Public libraries should cater to public interest in } \\
\text { contemporary issues without promoting or }\end{array}$ & 537 & 98.4 & 8 & 1.5 & 1 & .2 \\
\hline $\begin{array}{l}\text { suppressing particular beliefs or ideas. } \\
\text { Public libraries should RESIST attempts by individ- } \\
\text { uals or groups to restrict access to information } \\
\text { and ideas. }\end{array}$ & 483 & 88.6 & 45 & 6.1 & 17 & 3.1 \\
\hline $\begin{array}{l}\text { Public libraries should CONCEDE to attempts } \\
\text { by individuals or groups to restrict access to } \\
\text { information and ideas. }\end{array}$ & 13 & 2.4 & 48 & 8.8 & 484 & 88.8 \\
\hline
\end{tabular}


These statements were analyzed with a $t$-test, with the basic demographic characteristics (age, gender, LIS degree, years of experience, community size, community type, and political leaning of community). Significant results are reported here (see table 5 for detailed statistics). Age was significant for two statements, and gender was significant for three statements. Younger respondents thought public libraries should cater to the public interest in contemporary issues and should resist attempts to restrict access to information. Male respondents were more strongly in favor of providing a variety of viewpoints, resisting attempts to restrict access, and in opposition to conceding to attempts to restrict access.

Having an MLS degree was significant for all of these statements pertaining to intellectual freedom. Those respondents with an MLS degree were more likely to disagree that public libraries should concede to attempts to restrict access to information. Those with MLS degrees were more likely to agree that public libraries should provide a variety of sources, that public libraries should not promote or suppress certain ideas, and that public libraries should resist attempts to restrict access. Overall, those with MLS degrees were more likely to be aligned with stances taken by the ALA.

In terms of community characteristics, community size and community type were significant factors for all statements. The political leaning of the community was not significant for any statements.

Generally, the significant differences were between small and midsized communities (and sometimes large communities). Respondents from small communities were more likely to disagree that public libraries should cater to public interest in contemporary issues and that libraries should resist efforts to restrict access. Small-town residents were more likely to agree that libraries should concede to efforts to restrict access. Respondents from medium and large towns were more likely to strongly agree that libraries should provide materials from a variety of sources. Overall, those from small communities were somewhat less likely to support ALA positions.

When examining type of community, rural areas were often a significant factor (compared with cities, towns, and suburbs). Respondents from rural areas were less likely to strongly agree that libraries should have a variety of sources, that libraries should cater to the public interest, and that libraries should resist attempts to restrict access to information; rural respondents also were less likely to strongly disagree that libraries should concede to attempts to restrict access. In summary, rural respondents were in general less likely to endorse statements supported by ALA guidance.

\section{Personal Beliefs}

In the final portion of the survey, respondents were asked about how much they agreed with key ALA documents about intellectual freedom and how their personal and professional perspectives were similar. Respondents were asked to what extent they agreed with the following 


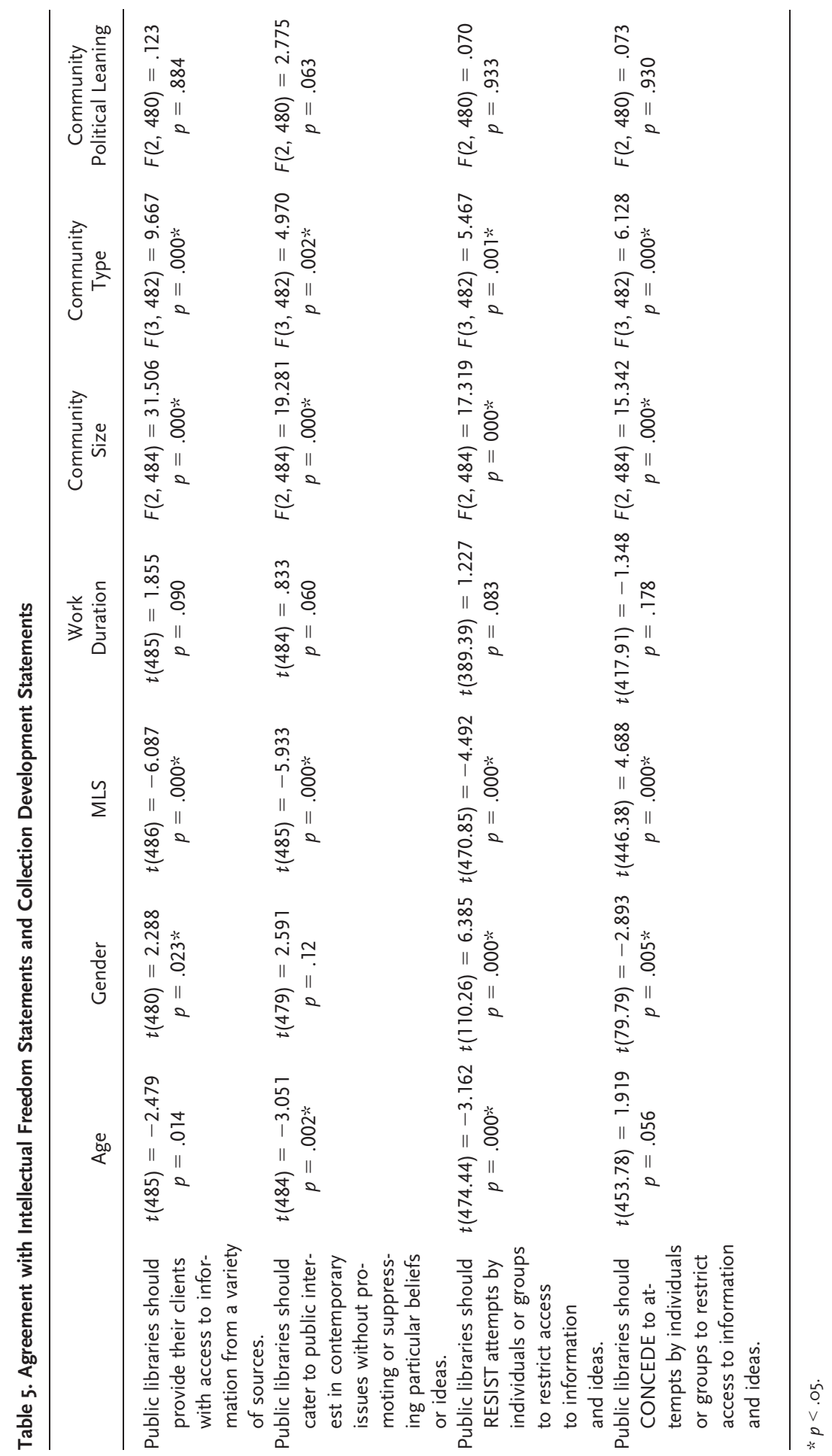

This content downloaded from 128.163.002.206 on December 13, 2019 18:54:27 PM

All use subject to University of Chicago Press Terms and Conditions (http://www.journals.uchicago.edu/t-and-c). 
Table 6. Agreement with ALA Code of Ethics

\begin{tabular}{lrr}
\hline & $n$ & $\%$ \\
\hline Strongly agree & 297 & 60.9 \\
Agree & 166 & 34.0 \\
Neither agree nor disagree & 20 & 4.1 \\
Disagree & 3 & .6 \\
Strongly disagree & 2 & .4 \\
\end{tabular}

statement from the Code of Ethics: "We uphold the principles of intellectual freedom and resist all efforts to censor library materials." As shown in table 6, the overwhelming majority of respondents agreed with this: $94.9 \%$ of librarians agreed or strongly agreed with this statement (the level of agreement is so strong that it is not possible to calculate statistical correlation with the various demographic variables, such as having an MLS degree or type of community).

Similarly, respondents were asked whether they agreed with the following statement from the ALA about intellectual freedom: "It is the right of every individual to both seek and receive information from all points of view without restriction.” Table 7 shows that, again, most respondents agreed with this statement. Only 1 respondent disagreed, only 15 registered neither agreement nor disagreement, and 473 agreed in some degree (again, with such overwhelming support, it is impossible to calculate correlations with the various demographic variables).

When asked if their personal beliefs were ever at odds with the "official stance on intellectual freedom by the American Library Association," 39.8\% responded "yes" (table 8). More than 22\% said they were unsure whether there was tension between their personal beliefs and the ALA stance on intellectual freedom. Nearly $40 \%$ said they saw no conflict between their personal beliefs and the ALA stance on intellectual freedom.

This question was cross-tabulated with the variables of age, gender, MLS, work duration, community size, community type, and community political leaning (see table 9). Respondents with an MLS degree were significantly more likely to say there was no conflict between their personal beliefs and the ALA stance $(p=.002)$. Those in large cities (population $>100,000$ ) were

Table 7. Agreement with ALA Statement about Intellectual Freedom

\begin{tabular}{lrr}
\hline & $n$ & $\%$ \\
\hline Strongly agree & 320 & 65.4 \\
Agree & 153 & 31.3 \\
Neither agree nor disagree & 15 & 3.1 \\
Disagree & 1 & .2 \\
Strongly disagree & 0 & .0
\end{tabular}


Table 8. Have You Ever Found Your Personal Beliefs to Be at Odds with the Official Stance on Intellectual Freedom by the American Library Association?

\begin{tabular}{lrr}
\hline & $n$ & $\%$ \\
\hline Yes, often & 18 & 3.7 \\
Yes, occasionally & 176 & 36.1 \\
Not sure & 110 & 22.5 \\
No, not at all & 184 & 37.7 \\
\end{tabular}

less likely to report conflict $(p=.000)$. Similarly, those in cities and suburbs reported less conflict between their personal beliefs and the ALA stance on intellectual freedom ( $p=.034)$.

Approximately 100 people left further comments to elaborate on this. Several people commented that their religious faith caused conflict with the ALA stance on intellectual freedom. For example, one respondent said, "We come from a primarily Christian community. . . I've had atheists ask why we have nothing within our library about atheism. Due to my own beliefs (and the beliefs of the community) it's been difficult to willingly acquire these items." Such comments seem to point to a gap in the collecting practices of at least a few librarians; some patrons may be un- or underserved by these and similar librarians. However, another respondent said, "I am a fundamentalist Christian. For myself, I am against abortion, gay marriage, sexually explicit materials, and Wicca/Satanic worship, etc. However, as a librarian, that is not my stance. I have taught Intellectual Freedom classes."

Others voiced concerns about pornography and internet filters: "Pornography is the biggest issue. I don't think adults have the right to openly view pornography in the library because it is not appropriate for children to see and it makes a significant portion of the population in my community uncomfortable.” This group of respondents believes that the ALA's stance on internet filtering and pornography does not correspond to the realities of working in a public library and dealing with the public. They would argue that using internet filters is a better way to serve their communities.

Table 9. Personal Beliefs at Odds with Official ALA Stance on Intellectual Freedom

\begin{tabular}{|c|c|c|c|c|c|c|}
\hline Age & Gender & MLS & $\begin{array}{c}\text { Work } \\
\text { Duration }\end{array}$ & $\begin{array}{l}\text { Community } \\
\text { Size }\end{array}$ & $\begin{array}{c}\text { Community } \\
\text { Type }\end{array}$ & $\begin{array}{c}\text { Community } \\
\text { Political } \\
\text { Leaning }\end{array}$ \\
\hline $\begin{array}{r}\chi^{2}(1)= \\
6.284\end{array}$ & $\begin{array}{c}\chi^{2}(1)= \\
2.699\end{array}$ & $\begin{array}{c}\chi^{2}(1)= \\
14.805\end{array}$ & $\begin{array}{c}\chi^{2}(1)= \\
1.844\end{array}$ & $\begin{array}{c}\chi^{2}(2)= \\
24.506\end{array}$ & $\begin{array}{c}\chi^{2}(1)= \\
18.079\end{array}$ & $\begin{array}{c}\chi^{2}(2)= \\
10.910\end{array}$ \\
\hline$p=.99$ & $p=.440$ & $p=.002 *$ & $p=.605$ & $p=.000 *$ & $p=.034 *$ & $p=.091$ \\
\hline
\end{tabular}

$* p<.05$. 
Relatedly, several comments expressed concern about the ALA stance on intellectual freedom vis-à-vis community libraries. For example, one librarian said,

Here is my main concern with the ALA's stance for absolute intellectual freedom: public libraries are owned by their communities, not the ALA. While it is right in principle to stand for absolute intellectual freedom, it is also right to consider that libraries rely on the good will of the communities who operate and support them. . . In real life, the desire for absolute intellectual freedom must be balanced by community sensibilities in order to maintain the good will of the people who financially support libraries. Library collections should offend everyone at some point, but librarians should also take care to offend as inoffensively as possible.

More pointedly, another respondent said that the ALA stance "does not represent conservative communities well. It would be unwise to purchase materials for the library which would be removed or never circulated at the library because of offensive content."

Conversely, some respondents argued that following the ALA stance on intellectual freedom was in fact a way to serve their communities. One said, "Regardless of where I stand on a subject, if I believe my patrons want certain material or I feel it completes a balance of viewpoints in our collection, I'll buy the material." These respondents indicate that the ALA stance on intellectual freedom supports a well-rounded collection, which is fundamental to serving their communities effectively.

Finally, many people commented that they did not perceive their personal beliefs to be at odds with the ALA stance on intellectual freedom. One said, "Do I have books on my shelf that I find offensive? Of course I do. But that's okay." Another respondent added, "I once found a book describing how global warming was a hoax and that it was a plot by liberals to undermine US wealth. I wanted to throw the book out so badly, but it sits on the shelf still. If I didn't find my personal beliefs at odds with the collection sometimes, I'd be a little concerned." These librarians saw their personal and professional beliefs about intellectual freedom in alignment.

\section{Conclusion}

This study examined public librarians' attitudes and actions regarding intellectual freedom, focusing on those with some degree of control over collections and located in the midwestern United States. Librarians overwhelmingly indicated agreement with core ALA stances on intellectual freedom, although nearly 40\% reported some tension between their personal and professional beliefs.

In the second part of this study (in a subsequent article), we will see how these perspectives on intellectual freedom align with and inform collection development practices within these 
public libraries; additional questions from this survey asked about collection development practices. In addition, the data from both articles will be analyzed for broad themes and initial conclusions.

\section{References}

ALA (American Library Association). 2018a. "Code of Ethics.” http://www.ala.org/tools/ethics.

ALA (American Library Association). 2018b. "Core Values.” http://www.ala.org/advocacy/intfreedom /corevalues.

ALA (American Library Association). 2018c. "Frequently Challenged Books." http://www.ala.org/advocacy /bbooks/frequentlychallengedbooks.

ALA (American Library Association). 2018d. "Intellectual Freedom and Censorship Q \& A." http://www.ala .org/advocacy/intfreedom/censorship/faq.

ALA (American Library Association). 2018e. "Interpretations of the Library Bill of Rights." http://www.ala .org/advocacy/intfreedom/librarybill/interpretations.

ALA (American Library Association). 2018f. "Library Bill of Rights." http://www.ala.org/advocacy /intfreedom/librarybill.

Asheim, Lester. 1953. "Not Censorship but Selection." Wilson Library Bulletin 28:63-67. http://www.ala.org /advocacy/intfreedom/NotCensorshipButSelection.

Busha, Charles. 1972. "Intellectual Freedom and Censorship: The Climate of Opinion in Midwestern Public Libraries." Libraru Ouarterly 42 (3): 283-301.

Connaway, Lynn S., and Marie L. Radford. 2017. Research Methods in Library and Information Science. 6th ed. Santa Barbara, CA: Libraries Unlimited.

Harkovitch, Michael, Amanda Hirst, and Jenifer Loomis. 2003. "Intellectual Freedom in Belief and Practice." Public Libraries 42 (6): 367-74.

Knox, Emily J. M. 2014. “The Books Will Still Be in the Library': Narrow Definitions of Censorship in the Discourse of Challengers." Library Trends 62 (4): 740-49.

Monks, Kathleen M., Anne M. Gaines, and Caitlin A. Marineau. 2014. "A Statewide Survey of Censorship and Intellectual Freedom" (submitted manuscript). Library Philosophy and Practice. http://digitalcommons .unl.edu/libphilprac/1083.

Moody, Kim. 2004. “Censorship by Queensland Public Librarians: Philosophy and Practice.” Aplis 17 (4): $168-85$.

Moody, Kim. 2005. “Covert Censorship in Libraries: A Discussion Paper.” Australian Libraru Journal 54 (2): $138-47$.

Oltmann, Shannon M. 2016. "Public Librarians' Views on Collection Development and Censorship.” Collection Management 41 (1): 23-44.

Shannon M. Oltmann: associate professor in the School of Information Science at the University of Kentucky. Oltmann received her PhD from Indiana University. Her research interests include censorship, intellectual freedom, information policy, public libraries, privacy, and qualitative research methods. She has presented her research at academic conferences such as the Information Ethics 
Roundtable, the annual conference of the Association for Information Science and Technology, the iConference, and the International Congress on Qualitative Inquiry. Her work has been published in the Journal of the American Society for Information Science and Technology, Library Quarterly, Public Libraries Quarterly, Collection Management, Libri, and Library and Information Science Research. Email: shannon.oltmann@uky.edu. 